\title{
Does Merger Type or Industry Affect Operating Performance of Acquiring Firms? A Long-Term Merger Performance Study in India
}

\author{
Meher Pramod Mantravadi \\ ICFAI Business School, Hyderabad, India \\ Email: pmantravadi@ibsindia.org
}

How to cite this paper: Mantravadi, M. P. (2020). Does Merger Type or Industry Affect Operating Performance of Acquiring Firms? A Long-Term Merger Performance Study in India. Theoretical Economics Letters, 10, 696-717.

https://doi.org/10.4236/tel.2020.103043

Received: May 11, 2020

Accepted: June 27, 2020

Published: June 30, 2020

Copyright $\odot 2020$ by author(s) and Scientific Research Publishing Inc. This work is licensed under the Creative Commons Attribution International License (CC BY 4.0).

http://creativecommons.org/licenses/by/4.0/

\begin{abstract}
Mergers and Acquisitions (M\&As) are being increasingly used the world over, for improving competitiveness of firms through gaining greater size and/or market share, broadening the product/service portfolio, reducing business/financial risk, entering new markets and geographies, and consolidation for achieving economies of scale etc. While there has been lot of hype and hope around mergers, and research about stock market reactions to such announcements, it is important to examine, if merging with other firms in same or other industries, actually improves the financial operating performance, for justifying such merger activities. This research study has aimed to study the impact of mergers on the operating performance of acquiring firms, by examining pre-merger and post-merger financial performance ratios, using the sample set of publicly traded acquiring firms in India between 1991-2015. Further, the sample has been segregated to study the impact for 1) mergers occurring among different industry segments, and 2) mergers between acquiring and acquired firms belonging to same industry (horizontal or vertical), or between firms in unrelated industries (conglomerate). The results from the analysis suggest that there are variations in terms of impact of mergers on operating performance, in different industry sectors in India. In particular, there was a positive impact on profitability for acquiring firms in the Banking \& Financial Services industry, while the impact was significantly negative for mergers in Sugar \& Agri-Products, Pharmaceutical and Textiles Sectors. The impact was mildly negative for Chemicals Sector, and mixed impact for the other sectors. Also, mergers seem to have caused significant decline in returns performance for horizontal mergers, while the impact has been neutral for vertical and conglomerate mergers.
\end{abstract}

\section{Keywords}

M\&A, Mergers, Acquisitions, Operating Performance, India, Industry, 


\section{Introduction}

In today's globalized economy, competitiveness and competitive advantage have become the buzzwords for corporates around the world. Corporates worldwide have been aggressively trying to build new competencies and capabilities, to remain competitive and to grow profitably. Strategic decisions such as mergers and acquisitions are being increasingly resorted to by companies, for one or more of the following reasons:

1) Attain greater market share, acquire additional brands or complementary products, cannibalize competing brands and businesses; globalise in a short span of time.

2) Gain access to additional manufacturing capacities to realize improved infrastructure and capitalize on economies of scale.

3) Acquire undervalued assets from distressed firms to enhance own scale.

4) Gain complementary strengths and enhancing managerial skill sets and competencies.

5) Capitalize on organizational synergies and reap financial/cost advantages.

\subsection{Global Trends in Mergers and Acquisitions}

There has been increased global merger and acquisition activity in recent years, aided by globalisation of market places, easing of regulatory systems for foreign direct investments, as well as international bilateral and multilateral agreements and treaties.

Global merger and acquisition activity in the first nine months of 2018 set a record, eclipsing a previous high reached on the eve of the financial crisis more than a decade ago, as shown in Figure 1 below, from Thomson Reuters report in Financial Times daily, of 18 Sept, 2018.

As per the same report, the value of M\&A deals in India has also hit an all-time high during 2018, compared to 2017, captured in Figure 2 below.

\section{Mergers and Acquisitions in Indian Industry}

The pace for mergers and acquisitions activity in India picked up in response to various economic reforms introduced by the Government of India since 1991, to push for economic liberalization and globalization. The Indian economy has undergone a major transformation and structural change following the economic reforms. In the liberalized economic and business environment, "size and competence" have become the focus of every business enterprise in India, as companies realized the need to grow and expand in businesses that they understand well, to face growing competition. Thus, several leading corporates have undertaken restructuring exercises to sell off non-core businesses, and to create 
stronger presence in their core areas of business interest. Mergers and acquisitions emerged as one of the most effective methods of such corporate restructuring, and have therefore, become an integral part of the long-term business strategy of corporates in India.

A survey among Indian corporate managers on M\&As in 2006 by Grant Thornton found that Mergers \& Acquisitions are a significant form of business strategy today for Indian Corporates. $19 \%$ of the respondents to the Survey stated that they do not believe in M\&As, while $81 \%$ looked at it as a part of strategy or will look at it opportunistically, as shown in Figure 3 below.

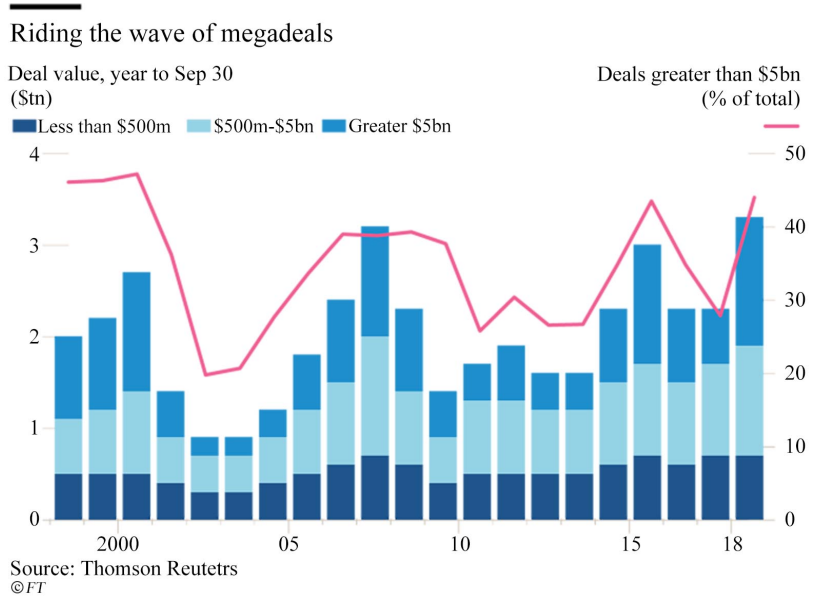

Figure 1. Global M\&A activity in the new Millennium. Deals saw a 39 per cent jump from 2017, as companies raced to remake themselves in the face of sweeping technological change. Corporate executives were seen taking advantage of record stock prices, buoyant consumer confidence and relatively low borrowing costs, according to Thomson Reuters ${ }^{1}$.

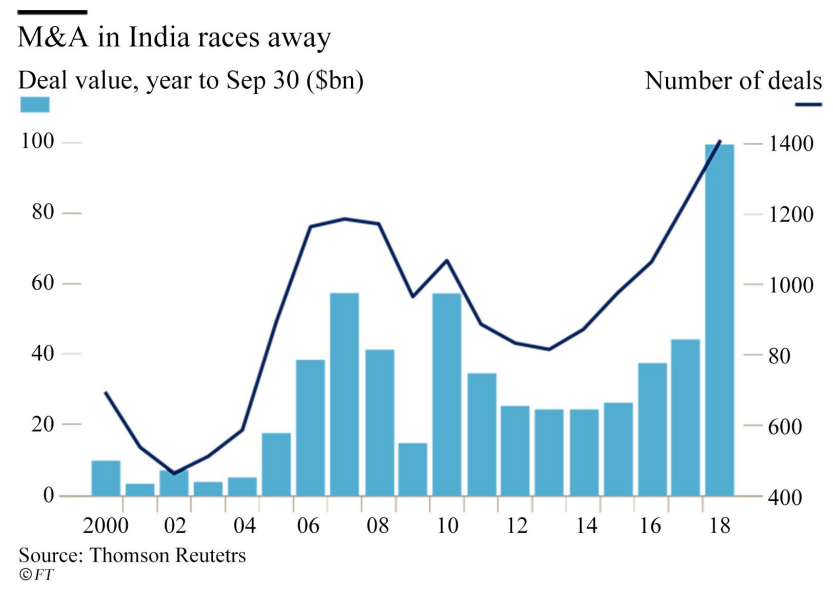

Figure 2. M\&A activity in India in the new Millennium. The surge in activity had come on all fronts-all time high inbound and domestic acquisitions, as well as outbound transactions. The largest contributor to Indian deal flows was domestic consolidation, where an aggressive new bankruptcy law was forcing control of indebted companies to change hands.

${ }^{1}$ Thomson Reuters report in Financial Times daily, 18 Sept 2018. 


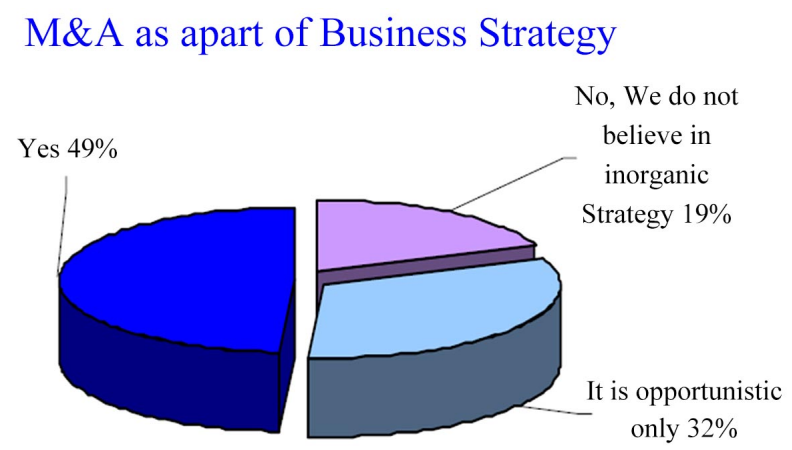

Figure 3. M\&A as part of Business Strategy for Indian Firms. Source: Grant Thornton (India), The M\&A and Private Equity Scenario, 2006.

The three main objectives (as captured in Table 1 below) behind any M\&A transaction, for corporates were found to be: 1) improving revenues and profitability, 2) faster growth in scale and quicker time to market, and 3) acquisition of new technology or competence.

Given this context, this study has aimed to examine the performance of companies that have gone through mergers in India, in the post-reforms period, and see if mergers had a significant impact on such companies. More specifically, the study has aimed to study mergers of firms in different industry sectors in India, to see if there are variations in the impact, for different industries.

Further, the study also looked at differences of impact on performance, across three different types of Mergers, from the sample chosen:

- Horizontal merger, where a company acquires and merges with a similar firm from the same industry, and usually with similar product/services portfolio.

- Vertical merger, where the target is in the same industry as the acquirer, but operating at a different stage of the production chain, either as a provider of inputs (backward integration) or as a user of the firm's products (forward integration).

- Conglomerate merger, where the acquiring firm and the acquired firm are apparently unrelated to each other, and usually from different industries.

\section{Review of Literature}

\subsection{Global Literature}

There have been numerous studies on mergers and acquisitions abroad, in the last four decades, and several theories have been proposed and tested for empirical validation. Researchers have studied the economic impact of mergers and acquisitions on industry consolidation, returns to shareholders following mergers and acquisitions, and the post-merger performance of companies. Whether or not a merged company achieves the expected performance is the critical question that has been examined by most researchers. Several measures have been postulated for analyzing the success of mergers. Such measures have included 
Table 1. Objectives of Indian corporates for M\&As.

\begin{tabular}{cc}
\hline Objective behind the M\&A Transaction & Responses (in \%) \\
\hline To improve revenues \& Profitability & $33 \%$ \\
Faster growth in scale and quicker time to market & $28 \%$ \\
Acquisition of new technology or competence & $22 \%$ \\
To eliminate competition \& increase market share & $11 \%$ \\
Tax shields \& Investment savings & $3 \%$ \\
\hline
\end{tabular}

Source: Grant Thornton (India), The M\&A and Private Equity Scenario, 2006.

both short term and long-term impacts of merger announcements, effects on shareholder returns of aborted mergers hostile takeover attempts and open offers etc.

A number of studies have been carried out in the developed capital markets of Europe, Australia, and the US, on evaluation of corporate financial performance following mergers. Lubatkin (1983) reviewed the findings of studies that have investigated either directly or indirectly the question, "Do mergers provide real benefits to the acquiring firm?" The review suggested that acquiring firms might benefit from merging because of technical, pecuniary and diversification synergies. Agrawal, Jaffe and Mandelker (1992) tested the performance of 937 acquiring firms over a 5-year post-merger period and found that the stocks of acquiring firms performed poorly after mergers, and that stockholders of acquiring firms suffered a statistically significant loss of about $10 \%$ over the 5-year post-merger period. However, this kind of research, along with their explanations, could be partially incorrect, as many other factors influence stock prices and their conclusions do not provide clear and conclusive results on the impact of M\&As. Healy, Palepu and Ruback (1992) examined post-acquisition performance for 50 largest US mergers between 1979 and 1984 by measuring post-merger cash flow performance, and concluded that operating performance of merging firms improved significantly following acquisitions, when compared to their industries. Ghosh (2001) re-examined the question of whether operating cash flow performance improves following corporate acquisitions, by a design that accounted for superior pre-acquisition performance, and found that merging firms did not show evidence of improvements in the operating performance following acquisitions. Weston and Mansingka (1971) studied the pre and post-merger performance of conglomerate firms, and found that their earnings rates significantly underperformed those in the control sample group, but after 10 years, there were no significant differences observed in performance between the two groups. The improvement in earnings performance of the conglomerate firms was explained as evidence for successful achievement of defensive diversification. Marina Martynova, Sjoerd Oosting and Luc Renneboog (1990) investigated the long-term profitability of corporate takeovers in Europe, and found that both acquiring and target companies significantly outperformed the median 
peers in their industry prior to the takeovers, but the profitability of the combined firm decreased significantly following the takeover. However, the decrease became insignificant after controlling for the performance of the control sample of peer companies. Kruse, Park, Park and Suzuki (2003) examined the long-term operating performance of Japanese companies using a sample of 56 mergers of manufacturing firms in the period 1969 to 1997. By examining the cash-flow performance in the five-year period following mergers, the study found evidence of improvements in operating performance, and also that the pre- and post-merger performance was highly correlated. The study concluded that control firm adjusted long-term operating performance following mergers in case of Japanese firms was positive but insignificant and there was a high correlation between pre- and post-merger performance. Jiang (2019) studied Horizontal Mergers and Acquisitions in the United States between 1995 and 2005, using event study method, and found that Horizontal M\&A enhanced the shareholder wealth of the targets in the short term, while causing loss of shareholder wealth of the bidders on the announcement day of M\&A. He also found the abnormal return of stocks was different in industries, with the most obvious impact on the shareholder wealth of targets in the manufacturing and wholesale and retail industries. Iordanis et al. (2012) studied Conglomerate and Non-Conglomerate mergers in Greece during 1998-2002, using financial ratios, and found that conglomerate mergers were more successful than non-conglomerates, in terms of liquidity ratios, but found no clear evidence from profitability ratios, activity ratios and investment ratios, if conglomerate mergers are more successful or not than non-conglomerates, as they observed ambiguous results. Zhang et al. (2018) explored the relationship between M\&As and firm performance, for listed Chinese pharmaceutical firms during 2008-2016, and found that value-chain-extension (vertical integration) M\&As, and technology-seeking M\&As were positively related to firm performance, whereas conglomerate M\&As had no significant correlation with firms' performance. Ayorinde and Ramon (2012), examined the effects of M\&As on the performance of select commercial banks in Nigeria during the period 2001-2010, and found enhanced financial performance after merger, as measured by an increase in deposit profile, profitability and gross earnings. Ahmed and Ahmed (2014), analyzed the post-merger financial performance of the acquiring banks in Pakistan during the period 2006-2010. The study has found that the financial performance of merging banks improved in the post-merger period but insignificantly. Post-merger profitability improved insignificantly, liquidity significantly, capital leverage insignificantly, while as assets quality parameter showed a significant deterioration. Musah et al. (2020) examined the consequence of mergers and acquisition on performance of 8 Commercial Banks in Ghana, during 2009-18, using Financial Ratios, and found a negative and significant association with net profit margin, positive but statistically insignificant relationship with return on assets and return on equity. Ikeda and Doi (1983) examined mergers in Japanese Manufac- 
turing firms during 1964-75, using parameters such as profitability, efficiency, growth, and $R \& D$, and found that the financial performance in respect of profitability was higher in the post-merger period. The few studies done on operating performance of acquiring firms, thus far, in other countries, have reported mixed results, with findings ranging from slightly positive to significantly negative impact on operating performance of acquiring companies, following mergers.

\subsection{Research in India}

The research on post-merger performance following mergers and acquisitions in India in the last 25 years has been limited. Beena (2007) analyzed the pre and post-merger performance of a sample of 115 acquiring firms in the manufacturing sector in India, between 1995-2000, using financial ratios, and found no evidence of improvement during the post-merger period, for the acquiring firms. Pawaskar (2001) analyzed the pre- and post-merger operating performance of 36 acquiring firms during 1992-95, using financial ratios ${ }^{2}$, and found that the acquiring firms performed better than industry average in terms of profitability. Mishra (2019) and Mishra \& Chandra (2010) studied the post-merger performance of pharmaceutical companies in India during 2001-08, and concluded that M\&As did not have any significant impact on profitability of the firms in the long run. Leepsa and Mishra (2012) studied mergers in manufacturing sector in India during 2003-2007, and found that financial performance of acquiring firms improved after merger, but results were not statistically significant. Ramakrishnan (2008) analysed a sample of 87 domestic mergers, using cash flow accounting measures, and found that operating efficiency has improved post-merger, due to synergistic benefits. Rani, Yadav, and Jain $(2013,2015)$ investigated the impact of mergers on corporate performance of acquiring firms in India, during 2003-2008, and observed that there was significant improvement in their profitability. Duggal (2015) studied mergers of Indian pharmaceutical companies during 2000-06, and found a positive impact in the first year after merger on the profitability of acquiring firms, but the impact was not sustained in the subsequent 3-year and 5-year periods. Khan (2012) studied post-merger firms in Indian Banking industry during 2001-10, and concluded that mergers caused a positive improvement in financial performance of acquiring firms. Sinha et al. (2010) examined M\&As of selected financial institutions in India during 2000-2008, and concluded that M\&A deals enabled acquiring firms to generate value. Shah (2018) studied M\&As in chemical and fertilizer sector of India, and found that the operating performance and returns to shareholders' improved, post-merger, but the improvements were not statistically significant. Mantravadi and Reddy (2008) studied mergers during 1991-2003, and found

${ }^{2}$ Ratios used were: Operating Return on Assets (PBIDT/Net Assets), Growth Rate (average growth rate in total assets), Leverage (Total Debt/(Total Debt + Equity Capital)), Tax Provision (Tax/Operating Profit) and Liquidity ((Current Assets - Inventory)/Current Liabilities). 
that mergers have positive impact on profitability of firms in the banking \& financial services industry.

Thus, empirical testing of corporate performance following mergers of Indian companies has been quite limited so far, with most of the studies focused specifically on selected sector-wise impact of mergers, using small samples, and over limited periods of time, which undermines proper measurement of the impact, due to the merger process.

\section{Research Objective}

Considering the limited research on mergers and acquisitions in Indian industry, the present research study has been aimed at adding to existing studies, by reviewing the performance of acquiring firms going through mergers in different industry sectors in India, in the post-reforms period, over a longer period of time, from 1991-2015. The study has attempted to investigate and see if there are any significant deviations in the results achieved by mergers, in different industry sectors in India. In addition, the mergers are also segregated by type (viz. Horizontal, Vertical and Conglomerate), and examined to see if there are different results depending on the merger type.

\subsection{Research Hypotheses}

The following hypotheses have been formulated, for this research study:

H1: Type of industry does not affect the change in operating performance of acquiring firms, following mergers.

$\mathrm{H} 2$ : Type of Merger does not affect the change in operating performance of acquiring firms, after merger.

\subsection{Methodology}

The pre and post-merger operating performance of the acquiring firms was measured using a set of accounting ratios, as under:

- Operating Profit Margin (PBDIT/Net Sales) ${ }^{3}$,

- Net Profit Margin (PAT/Net Sales) ${ }^{4}$,

- Return on Net worth (PBIT/Capital Employed) ${ }^{5}$,

- Return on Capital Employed (PAT/Net Worth) and

- Debt Equity Ratio (Book Value of Debt/Book Value of Equity)

The pre-merger and post-merger averages for above financial ratios were computed for 3 years prior to, and 3 years after the effective date for the merger. The merger completion year is denoted as year 0 . For the years prior to a merger, the operating ratios of the acquiring firm alone are considered. Post the merger, the operating ratios for the combined firm are taken. The post-merger performance was compared with the pre-merger performance and tested for sig-

${ }^{3}$ PBDIT is Profit before Depreciation, Interest and Tax.

${ }^{4} \mathrm{PAT}$ is Profit after Tax.

${ }^{5} \mathrm{PBIT}$ is Profit before Interest and Tax. 
nificant differences, using paired " $\mathrm{t}$ " test, at a confidence level of $95 \%$ (two-tailed).

One of the limitations of prior research on post-merger performance, is the ignoring of the amalgamation aspect, following the acquisition. If an acquiring firm buys out shares of the target firm, but manages the acquired firm as a "subsidiary", the reported financial results may not reflect the effect of true consolidation of the operations of the two firms, and thereby complete extraction of the synergistic benefits. Hence the present research study has limited the sample cases, to stock-for-stock mergers, where the acquired firm is completely integrated into the acquiring firm, and is delisted from the Stock Exchanges. Since the present study is investigating whether corporate acquisitions create synergistic gains as suggested by the normative literature, the financial ratios selected above, reflect operating efficiency manifestations. The present study deviates in methodology from similar studies, in that the financial results of the acquiring and acquired firms are not aggregated, while measuring the pre-merger performance. The advantage of this approach is that it provides evidence based on actual financial accounting based realizations, and an unbiased analysis of operating efficiency gains from mergers, rather than on future expectations, market psychology, or investor perceptions sentiment embedded in asset prices, which have been the main focus in some of the event studies done by other researchers earlier.

\subsection{Data Collection and Analysis}

The sample of mergers analysed for the purpose of this research comprised of those that occurred in India during the period of 1991-2015. The period post-2015 has not been considered because such cases would not have the audited accounting data for 3 years post the completion of the merger. The sample for the study primarily included mergers by public limited companies listed on Stock Exchanges, and Cross-border mergers were excluded from the sample. Only stock-for-stock mergers are included in the sample. Further, companies in the sample were also screened to ensure that they had not engaged in further mergers/acquisitions within 3 years after the merger under study. List of companies involved in mergers during 1991-2015 were compiled from several sources like investment web sites, web sites of Stock Exchanges and Securities \& Exchange Board of India (SEBI) (for details of companies making open offers for takeovers), and Financial Databases like Capitaline and CMIE Prowess. To such lists, the screening criteria were applied, to arrive at the final sample. Merger cases where at least two years of data was not available for pre-merger period and at least three years data for post-merger period were removed from the study sample. Also excluded were firms which were engaged in mergers/acquisitions within 3 years after the merger considered for the research study, to enable proper comparison of pre- and post-merger data, and ensure that data pertaining to a single instance of merger is being analysed (to reduce 
sample bias caused by firms that are involved in multiple mergers at frequent intervals). The final sample of firms selected for the study, based on above criteria, totalled to 257 .

The sample of mergers were further segregated, after careful scrutiny of the merger context and background (shown in Table 2 below), based on the Type of Merger (Horizontal, Vertical or Conglomerate).

The total sample of mergers was also segregated on the basis of the Industry to which the acquiring firm belonged (as shown in Table 3 below).

\subsection{Financial Data Collection for Sample Firms}

Data of operating performance ratios for up to three years prior and three years after the acquisition year for each acquiring company was extracted from Prowess. The examination of financial performance of the acquirer firm up to three years after the acquisition is to allow a time-period that is sufficient for any potential economic gains to be realized. The final sample of the merger cases for this study, had the following industry-wise distribution.

Table 2. Distribution of mergers by category type.

\begin{tabular}{ccc}
\hline Type of Merger & Number & $\%$ of total \\
\hline Horizontal & 170 & $66 \%$ \\
Vertical & 23 & $9 \%$ \\
Conglomerate & 64 & $25 \%$ \\
Total & 257 & $100 \%$ \\
\hline
\end{tabular}

Table 3. Industry wise distribution of merging firms in the sample.

\begin{tabular}{ccc}
\hline Industry (acquiring company) & No of mergers & \% of Total \\
\hline Banking \& Financial Services & 32 & $12 \%$ \\
Construction \& Building Materials & 23 & $9 \%$ \\
Electrical \& Electronic Equipment & 26 & $10 \%$ \\
Organic and Inorganic Chemicals & 24 & $9 \%$ \\
Pharmaceuticals & 20 & $8 \%$ \\
Metals, Glass and Plastics Manufacturing & 31 & $12 \%$ \\
Automobile and Ancillaries Manufacturing & 11 & $4 \%$ \\
Sugar, Beverages and Agri-Products & 24 & $9 \%$ \\
Textiles & 23 & $9 \%$ \\
Information Technology & 10 & $4 \%$ \\
Others & 33 & $13 \%$ \\
Total & 257 & $100 \%$ \\
\hline
\end{tabular}




\subsection{Data Analysis}

To test if there are any industry specific trends in operating performance of merging companies, the data on mergers in each of the industries were aggregated, in two ways:

1) Based on classification of the mergers into Horizontal, Vertical and Conglomerate types.

2) Based on sample cases segregated for each of the different industry sectors.

Financial ratios reflecting 3-year average pre-merger and post-merger performance, were measured and tested to see if there was any change in operating performance due to mergers, using "paired two sample t-test assuming equal variances" at confidence level of $95 \%$.

\section{Findings and Results}

\subsection{Analysis of Different Types of Mergers}

\subsubsection{Horizontal Mergers (Sample Size $=170$ )}

Results from statistical analysis of the sample of horizontal mergers are shown below, in Table 4 .

The test results show that the average post-merger gross profitability margins have remained stagnant post the merger, and are also confirmed by the low $\mathrm{t}$-values of 0.6516 and 0.7965 . The average returns on net worth and capital employed, however, show significant declines, which are also statistically significant (high t-values of 2.869 and 4.355). The debt equity ratio indicates no significant change post the merger, and this is also confirmed by the low t-value of 0.9601 ).

These results suggests that firms have mostly engaged in horizontal mergers, with similarly profitable firms, but have been unable to derive synergies from the increased scale and scope of operations, and have suffered from poor returns on net worth and capital employed. The findings also seem to indicate that these mergers have been mostly driven by size aspirations, but lower utilization of the higher asset bases, have caused diminishing returns on the capital.

\subsubsection{Vertical Mergers (Sample Size $=23$ )}

Results from statistical analysis of the sample of vertical mergers are shown below, in Table 5.

Table 4. Mean pre-merger and post-merger ratios for acquiring firms in horizontal mergers.

\begin{tabular}{cccccc}
\hline & Pre-merger & Post-merger & $\begin{array}{c}\text { t-value }(0.05 \\
\text { significance) }\end{array}$ & $\begin{array}{c}p \text {-value } \\
(2 \text {-tail })\end{array}$ & $\begin{array}{c}\text { t-critical } \\
(2 \text {-tail })\end{array}$ \\
\hline Operating Profit Margin & 23.737 & 23.254 & 0.4524 & 0.6516 & 1.9741 \\
Net Profit Margin & 6.787 & 6.460 & 0.2583 & 0.7965 & -do- \\
Return on Net worth & 13.784 & 8.421 & 2.8691 & $\mathbf{0 . 0 0 4 6}$ & -do- \\
Return on Capital Employed & 15.250 & 10.845 & $\mathbf{4 . 3 5 4 7}$ & $\mathbf{0 . 0 0 0 0 2}$ & -do- \\
Debt Equity Ratio & 1.269 & 1.276 & -0.0501 & 0.9601 & -do- \\
\hline
\end{tabular}


Table 5. Mean pre-merger and post-merger ratios for acquiring firms in vertical mergers.

\begin{tabular}{cccccc}
\hline & Pre-merger Post-merger & $\begin{array}{c}\text { t-value }(0.05 \\
\text { significance) }\end{array}$ & $\begin{array}{c}\text { p-value } \\
(2 \text {-tail })\end{array}$ & $\begin{array}{c}\text { t-critical } \\
(2 \text {-tail })\end{array}$ \\
\hline Operating Profit Margin & 14.557 & 13.589 & 0.5804 & 0.5675 & 2.0739 \\
Net Profit Margin & -1.323 & 3.478 & -0.7393 & 0.4675 & - -do- \\
Return on Net worth & 14.347 & 9.582 & 1.2295 & 0.2318 & -do- \\
Return on Capital Employed & 15.362 & 13.002 & 1.2160 & 0.2369 & -do- \\
Debt Equity Ratio & 1.414 & 1.455 & -0.1543 & 0.8788 & -do- \\
\hline
\end{tabular}

The results show that the average post-merger gross profitability margins have declined, while net profit margins have improved, but the low t-values of 0.5804 and -0.7393 suggest that the differences are insignificant. Average returns on net worth and capital employed show a decline during the post-merger period, but these again seem to be not statistically significant when compared to the pre-merger period. The decline is also statistically validated, " $\mathrm{t}$ " values being above 2.0. The debt equity ratio also shows no change after merger, confirmed by $t$-value of -0.1543 . The above findings suggest that for the sample of Vertical Mergers, operating performance has not been impacted significantly (either positive or negative). The share of vertical mergers, in the Total Sample of Mergers, is also quite low (around 8\%) in India in the study period, suggesting that these type of mergers have also not been very popular in the Indian context.

\subsubsection{Conglomerate Mergers (Sample Size $=64$ )}

Results from statistical analysis of the sample of conglomerate mergers are shown below, in Table 6 .

The results from paired t-test analysis show that the gross profit and net profit margins have improved post the merger, but the low " $\mathrm{t}$ " values $(-0.4075$ and -0.4852 ) suggest that the difference is insignificant. However, the average returns on net worth and capital employed show a decline during the post-merger period, but the declines are not statistically validated, as indicated by the $t$-values of 0.6172 and 1.0558 . The debt equity ratio also shows a marginal increase after merger, but not statistically significant again ( $\mathrm{t}$-value of -1.0889 ). These findings suggest that for the sample of conglomerate mergers, mergers have slightly improved the profitability, but negatively impacted the returns on capital, which was likely caused by the increase in leverage and asset base, which have offset the margin improvement.

The variations in results across the different types of mergers as seen above, cause us to reject the null hypothesis, and state that there are differential levels of impact on operating performance of acquiring firms, for different types of mergers. 
Table 6. Mean pre-merger and post-merger ratios for acquiring firms in conglomerate mergers.

\begin{tabular}{cccccc}
\hline & Pre-merger Post-merger & $\begin{array}{c}\mathrm{t} \text {-value }(0.05 \\
\text { significance) }\end{array}$ & $\begin{array}{c}p \text {-value } \\
(2 \text {-tail })\end{array}$ & $\begin{array}{c}\text { t-critical } \\
\text { (2-tail) }\end{array}$ \\
\hline Operating Profit Margin & 17.335 & 17.991 & -0.4075 & 0.6850 & 1.9983 \\
Net Profit Margin & 1.947 & 3.382 & -0.4852 & 0.6292 & -do- \\
Return on Net worth & 8.858 & 6.462 & 0.6172 & 0.5393 & -do- \\
Return on Capital Employed & 13.604 & 11.525 & 1.0558 & 0.2951 & -do- \\
Debt Equity Ratio & 1.033 & 1.212 & -1.0889 & 0.2803 & -do- \\
\hline
\end{tabular}

\subsection{Analysis of Mergers in Various Industry Sectors}

\subsubsection{Sugar, Beverages \& Agri-Products Sector}

Results from statistical analysis of the sample of mergers in Sugar, Beverages \& Agri-Products Sector are shown below, in Table 7.

The results show that the average post-merger Operating Profit and Net Profit margins have declined, when compared to the pre-merger average. The decline in net profit margin is statistically significant, confirmed by the t-value of 2.0198 . The average returns on net worth and capital employed also show a significant decline, during the post-merger period, when compared to the pre-merger period. The declines are also statistically validated ( $t$-values of 3.0696 and 3.2027). The debt equity ratio also shows a significant increase after merger, suggesting that increase in leverage has impacted the profit margins and returns on net worth and capital employed.

The above results suggest that for this sector, mergers have not been beneficial, and have caused significant decline in the profit margins, as well as returns on capital deployed in the business. The increase in leverage \& the asset base through the merger, and lower asset utilization have caused diminishing profitability and returns on capital investment.

\subsubsection{Organic \& Inorganic Chemicals Sector}

Results from statistical analysis of the sample of mergers in Organic \& Inorganic Chemicals sector are shown below, in Table 8 .

The results show that the average post-merger operating profit and net profit margins have declined, when compared to the pre-merger average, but they are not statistically significant (" $t$ " values of 1.2161 and 0.6389 ). Similarly, the average returns on net worth and capital employed show a decline during post-merger period, but the decline is again not statistically significant (" $t$ " values of 0.6072 and 1.6242). The debt equity ratio does not show any major change before and after merger, (0.763 vs. 0.723$)$, also confirmed by the low "t" value of -0.3207 .

The above findings suggest that for the Organic \& Inorganic chemicals sector, mergers have caused marginal but statistically insignificant declines, both in profit margins and the returns on net worth and capital deployed in the business. 
Table 7. Mean pre-merger and post-merger ratios for acquiring firms in sugar, beverages \& Agri-products sector.

\begin{tabular}{cccccc}
\hline & Pre-merger & Post-merger & $\begin{array}{c}\text { t-value }(0.05 \\
\text { significance })\end{array}$ & $\begin{array}{c}p \text {-value } \\
(2 \text {-tail })\end{array}$ & $\begin{array}{c}\text { t-critical } \\
(2 \text {-tail })\end{array}$ \\
\hline Operating Profit Margin & 13.698 & 11.790 & 1.4250 & 0.168 & $\mathbf{2 . 0 6 8 7}$ \\
Net Profit Margin & 5.642 & 2.846 & 2.0198 & $\mathbf{0 . 0 5 5}$ & -do- \\
Return on Net worth & 17.505 & 4.464 & 3.0696 & $\mathbf{0 . 0 0 5}$ & -do- \\
Return on Capital Employed & 21.529 & 11.822 & 3.2027 & $\mathbf{0 . 0 0 4}$ & -do- \\
Debt Equity Ratio & 0.980 & 1.497 & -1.6520 & 0.112 & -do- \\
\hline
\end{tabular}

Table 8. Mean pre-merger and post-merger ratios for acquiring firms in organic \& inorganic chemicals sector.

\begin{tabular}{cccccc}
\hline & Pre-merger Post-merger & $\begin{array}{c}\text { t-value (0.05 } \\
\text { significance) }\end{array}$ & $\begin{array}{c}p \text {-value } \\
\text { (2-tail) }\end{array}$ & $\begin{array}{c}\text { t-critical } \\
\text { (2-tail) }\end{array}$ \\
\hline $\begin{array}{c}\text { Operating Profit Margin } \\
\text { Net Profit Margin }\end{array}$ & 13.738 & 11.850 & 1.2161 & 0.2363 & 2.0687 \\
Return on Net worth & 12.743 & 3.989 & 0.6389 & 0.5292 & -do- \\
Return on Capital Employed & 14.185 & 11.043 & 1.6242 & 0.1180 & -do- \\
Debt Equity Ratio & 0.723 & 0.763 & -0.3207 & 0.7513 & -do- \\
\hline
\end{tabular}

\subsubsection{Analysis of Mergers in Textiles Sector}

Results from statistical analysis of the sample of mergers in Textiles Industry are shown below, in Table 9.

The results show that all the post-merger profit margin averages have declined, when compared to the pre-merger averages, but the declines are not statistically significant, as indicated by the "t" values (1.1953 and 1.7253). However, the average returns on net worth and capital employed show a significant decline during the post-merger period, and the declines are statistically validated, with " $t$ " values of 1.8826 and 2.9849). The debt equity ratio does not show much change after merger ( 1.73 vs. 1.69 ), and this is also confirmed by the low " $t$ " value of -0.1364 .

The above findings suggest that for the Textiles sector, mergers have caused marginal declines in profit margins, and significant declines in the returns on Net Worth and Capital Employed, implying that the asset base has increased following merger, and the declining profit margins, on a higher asset base, has deteriorated the returns. This indicates that mergers have caused a deterioration in the performance of acquiring firms in this industry.

\subsubsection{Banking \& Financial Services}

Results from statistical analysis of the sample of mergers in Banking and Financial Services industry are shown below, in Table 10.

The results from the analysis show that the average post-merger operating profit margins have marginally increased, when compared to the pre-merger averages, and the " $\mathrm{t}$ " value (-1.8754), compared to the $\mathrm{t}$-critical value (2.0395), 
Table 9. Mean pre-merger and post-merger ratios for acquiring firms in textiles industry.

\begin{tabular}{cccccc}
\hline & Pre-merger Post-merger & $\begin{array}{c}\text { t-value }(0.05 \\
\text { significance) }\end{array}$ & $\begin{array}{c}p \text {-value } \\
(2 \text {-tail })\end{array}$ & $\begin{array}{c}\text { t-critical } \\
(2-\text {-tail })\end{array}$ \\
\hline Operating Profit Margin & 15.595 & 13.509 & 1.1953 & 0.2447 & 2.0739 \\
Net Profit Margin & 3.045 & 0.801 & 1.7253 & 0.0985 & -do- \\
Return on Net worth & 9.554 & -0.613 & 1.8826 & 0.0731 & -do- \\
Return on Capital Employed & 10.972 & 5.710 & 2.9849 & $\mathbf{0 . 0 0 6 8}$ & -do- \\
$\quad$ Debt Equity Ratio & 1.692 & 1.727 & -0.1364 & 0.8927 & -do- \\
\hline
\end{tabular}

Table 10. Mean pre-merger and post-merger ratios for acquiring firms in banking \& financial services industry.

\begin{tabular}{cccccc}
\hline & Pre-merger & Post-merger & $\begin{array}{c}\text { t-value }(0.05 \\
\text { significance })\end{array}$ & $\begin{array}{c}p \text {-value } \\
(2 \text {-tail })\end{array}$ & $\begin{array}{c}\text { t-critical } \\
(2 \text {-tail })\end{array}$ \\
\hline Operating Profit Margin & $\mathbf{5 5 . 1 1 9}$ & $\mathbf{6 1 . 8 7 2}$ & $-\mathbf{1 . 8 7 5 4}$ & $\mathbf{0 . 0 7 0 2}$ & $\mathbf{2 . 0 3 9 5}$ \\
Net Profit Margin & 12.951 & 15.615 & -0.5277 & 0.6015 & -do- \\
Return on Net worth & 11.304 & 12.484 & -0.3847 & 0.7031 & -do- \\
$\begin{array}{c}\text { Return on Capital Employed } \\
\text { Debt Equity Ratio }\end{array}$ & 11.753 & 11.640 & 0.0502 & 0.9602 & -do- \\
\hline
\end{tabular}

suggests that the difference is significant. The net profit margin also shows an increase $(15.615 \%$ vs. $12.951 \%)$, but this is not statistically significant, as suggested by the " $t$ " value of -0.5277 . Similarly, the average return on net worth showed a marginal increase, while return on capital employed showed a marginal decline, during the post-merger period, but these changes are not statistically significant ( $t$-values of -0.3847 and 0.0502 ). The debt equity ratio however, shows a statistically significant rise after merger (1.86 vs. 1.24$)$, confirmed by the $\mathrm{t}$-value of -2.053 .

The above findings suggest that for the Banking \& Finance Sector, mergers have caused an improvement in the profit margins, though not fully substantiated statistically. The improvement in operating profit margins could be seen as an indicator of economies of scale. The returns on net worth and capital employed do not much change, indicating that the increased profit margins have not translated into substantial returns on the increased total assets base, partly due to the increase in interest costs due to higher leverage. This seems to indicate that for this industry, mergers could be beneficial in improving operational efficiency and increase profitability, through consolidation of operations, if the leverage is given due consideration while planning the merger.

\subsubsection{Pharmaceuticals}

Results from statistical analysis of the sample of mergers in Pharmaceuticals Industry are shown in Table 11 below. 
The results show that the average post-merger operating profit margins have improved, but net profit margins have declined, post the mergers, but these are not statistically significant ( $t$-values of -1.1353 and 0.3692 ). However, the average returns on net worth shows a statistically significant decline, during the post-merger period (11.97\% vs. $25.2 \%$, and t-value of 2.3693 ). Returns on capital employed also show a decline, close to being statistically significant $(16.99 \%$ vs. $21.51 \%$, and $t$-value of 1.556 ) when compared to the pre merger period. The debt equity ratio also shows a decline, which is also not statistically significant ( $t$-value of 1.228).

The above findings suggest that for the Pharmaceuticals Sector, mergers have not impacted profitability margins, but had a significant negative impact on the returns on net worth and capital employed in the business. This indicates that for this industry, the consolidation through mergers has translated into lower returns on capital, due to increase in the scale of operations and assets, but without much improvement in net profit margins in spite of lowered leverage. The focus of these mergers seem to be more of consolidation, by merging firms with accumulated losses and depreciation, with stronger firms, to become bigger in terms of asset base and business size.

\subsubsection{Electrical and Electronic Equipment}

Results from statistical analysis of the sample of mergers in Electrical and Electronic Equipment industry are shown below, in Table 12 .

Table 11. Mean pre-merger and post-merger ratios for acquiring firms in pharmaceuticals industry.

\begin{tabular}{cccccc}
\hline & Pre-merger Post-merger & $\begin{array}{c}\text { t-value }(0.05 \\
\text { significance) }\end{array}$ & $\begin{array}{c}p \text {-value } \\
(2 \text {-tail) }\end{array}$ & $\begin{array}{c}\text { t-critical } \\
(2 \text {-tail })\end{array}$ \\
\hline Operating Profit Margin & 18.400 & 20.320 & -1.1353 & 0.2704 & 2.0930 \\
Net Profit Margin & 9.001 & 8.302 & 0.3692 & 0.7160 & -do- \\
Return on Net worth & 25.206 & 11.966 & 2.3693 & 0.0286 & -do- \\
Return on Capital Employed & 21.514 & 16.994 & 1.5558 & 0.1363 & -do- \\
Debt Equity Ratio & 1.231 & 0.861 & 1.2277 & 0.2346 & -do- \\
\hline
\end{tabular}

Table 12. Mean pre-merger and post-merger ratios for acquiring firms in electrical and electronic equipment industry.

\begin{tabular}{cccccc}
\hline & Pre-merger Post-merger & $\begin{array}{c}\text { t-value (0.05 } \\
\text { significance) }\end{array}$ & $\begin{array}{c}p \text {-value } \\
\text { (2-tail) }\end{array}$ & $\begin{array}{c}\text { t-critical } \\
(2-t a i l)\end{array}$ \\
\hline Operating Profit Margin & 13.460 & 12.092 & 0.7988 & 0.4319 & 2.0595 \\
Net Profit Margin & 4.061 & 2.653 & 0.8246 & 0.4174 & -do- \\
Return on Net worth & 11.848 & 8.597 & 0.7798 & 0.4429 & -do- \\
Return on Capital Employed & 18.791 & 15.564 & 1.3110 & 0.2018 & -do- \\
Debt Equity Ratio & 0.835 & 0.891 & -0.3070 & 0.7614 & -do- \\
\hline
\end{tabular}


The results show that there were minor declines in operating and net profit margins in post-merger period, but the declines are not statistically significant ( $t$-values of 0.7988 and 0.8246 ). Similarly, there was a decline in the returns on net worth and capital employed, which are also not statistically significant (t-values of 0.7798 and 1.311). The debt equity ratio was also almost unchanged after merger. The above findings suggest that for this sector, mergers have caused a negative but statistically insignificant impact, on profitability margins and returns on capital, which suggests that the mergers were more likely aimed at consolidating businesses and assets, to become bigger and financially more stable.

\subsubsection{Manufacturing-Metals, Glass and Plastics}

Results from statistical analysis of the sample of mergers in Metals, Glass and Plastics Manufacturing sector are shown below, in Table 13.

The results show that the average post-merger operating profit margins have marginally declined, while net profit margins have improved, post the mergers, but these are not statistically significant (t-values of 0.3402 and -0.6989 ). The average returns on net worth and capital employed also show a marginal decline during the post-merger period, but these declines are not statistically significant ( $t$-values of 0.041 and 0.5146 ). The debt equity ratio also shows a decline, which is also again not statistically significant ( $\mathrm{t}$-value of 0.6228 ).

The above findings suggest that for this Sector, mergers have caused a minor but statistically insignificant decline in terms of profitability and returns. This indicates that for this industry group, the focus of the mergers seems to be more to becoming bigger in terms of asset base and business size, while lowering leverage and interest costs.

\subsubsection{Construction and Building Materials}

Results from statistical analysis of the sample of mergers occurred in Construction and Building Materials industry are shown below, in Table 14.

The results from the analysis show that the average post-merger operating profit margins have declined, while net profit margins have improved post the mergers, but these are not statistically significant ( $t$-values of 0.7817 and $-0.4677)$. The average returns on net worth and capital employed show a decline, during post-merger period, but these are again statistically not significant ( $\mathrm{t}$-values of 0.9936 and 0.7752 ). The debt equity ratio has declined marginally, but it is also statistically not significant.

The above findings suggest that for the Automobile and ancillaries Sector, mergers have caused marginal improvement in net profitability margins, due to reduction of interest costs, enabled by lower leverage, but the increased asset base has caused a decline in returns on capital in the business. The focus of the mergers in this sector seem to be the consolidation of operations by increasing asset base and lowering leverage, to face increased competition. 
Table 13. Mean pre-merger and post-merger ratios for acquiring firms in metals, glass and plastics manufacturing sector.

\begin{tabular}{cccccc}
\hline & Pre-merger Post-merger & $\begin{array}{c}\text { t-value }(0.05 \\
\text { significance) }\end{array}$ & $\begin{array}{c}p \text {-value } \\
(2 \text {-tail) }\end{array}$ & $\begin{array}{c}\text { t-critical } \\
(2 \text {-tail })\end{array}$ \\
\hline Operating Profit Margin & 15.429 & 14.425 & 0.3402 & 0.7361 & $\mathbf{2 . 0 4 2 3}$ \\
Net Profit Margin & 0.076 & 3.511 & -0.6989 & 0.4900 & -do- \\
Return on Net worth & 10.553 & 10.207 & 0.0410 & 0.9676 & -do- \\
Return on Capital Employed & 14.261 & 12.244 & 0.5146 & 0.6106 & -do- \\
Debt Equity Ratio & 2.091 & 1.765 & 0.4970 & 0.6228 & -do- \\
\hline
\end{tabular}

Table 14. Mean pre-merger and post-merger ratios for acquiring firms in construction and building materials industry.

\begin{tabular}{cccccc}
\hline & Pre-merger & Post-merger & $\begin{array}{c}\text { t-value (0.05 } \\
\text { significance) }\end{array}$ & $\begin{array}{c}p \text {-value } \\
(2 \text {-tail) }\end{array}$ & $\begin{array}{c}\text { t-critical } \\
(2 \text {-tail) }\end{array}$ \\
\hline Operating Profit Margin & 25.038 & 21.379 & 0.7817 & 0.4427 & 2.0739 \\
Net Profit Margin & 1.747 & 5.237 & -0.4677 & 0.6446 & -do- \\
Return on Net worth & 10.212 & 4.855 & 0.9936 & 0.3312 & -do- \\
Return on Capital Employed & 6.519 & 4.896 & 0.7752 & 0.4465 & -do- \\
Debt Equity Ratio & 1.533 & 1.184 & 1.0325 & 0.3131 & -do- \\
\hline
\end{tabular}

\subsubsection{Manufacturing-Automobiles and Ancillaries}

Results from statistical analysis of the sample of mergers in Automobiles and Auto-ancillaries Manufacturing sector are shown below, in Table 15.

The results of the analysis show that the average post-merger operating profit margins and net profit margins have improved post the mergers, but these are not statistically significant ( $\mathrm{t}$-values of -1.1783 and -0.8858 ). The average returns on net worth shows an improvement, while returns on capital employed show a decline, during the post-merger period, but these are again statistically not significant ( $t$-value of -0.5579 and 0.481 ). The debt equity ratio seems almost unchanged.

The above findings suggest that for the Automobile and ancillaries Sector, mergers have caused marginal improvement in profitability margins, probably due to rationalisation of costs, but these did not translate into significant improvements of returns on net worth and capital deployed in the business. The focus of the mergers in this sector seems to be the consolidation of operations through cost rationalisation, driven by heavy competition that impacts profit margins.

\subsubsection{Information Technology}

Results from statistical analysis of the sample of mergers in Information Technology sector are shown in Table 16 below.

The results show that the average post-merger operating profit and net profit margins have declined, post the mergers, but these are not statistically significant 
Table 15. Mean pre-merger and post-merger ratios for acquiring firms in automobiles and auto-ancillaries manufacturing sector.

\begin{tabular}{cccccc}
\hline & Pre-merger & Post-merger & $\begin{array}{c}\text { t-value }(0.05 \\
\text { significance) }\end{array}$ & $\begin{array}{c}p \text {-value } \\
(2 \text {-tail) }\end{array}$ & $\begin{array}{c}\text { t-critical } \\
(2 \text {-tail })\end{array}$ \\
\hline Operating Profit Margin & 9.514 & 10.700 & -1.1783 & 0.2660 & 2.2281 \\
Net Profit Margin & 2.677 & 3.457 & -0.8858 & 0.7160 & -do- \\
Return on Net worth & 6.602 & 11.123 & -0.5579 & 0.5892 & -do- \\
Return on Capital Employed & 13.422 & 12.172 & 0.4810 & 0.6409 & -do- \\
$\quad$ Debt Equity Ratio & 1.343 & 1.389 & -0.2149 & 0.8341 & -do- \\
\hline
\end{tabular}

Table 16. Mean pre-merger and post-merger ratios for acquiring firms in information technology.

\begin{tabular}{cccccc}
\hline & Pre-merger Post-merger & $\begin{array}{c}\mathrm{t} \text {-value (0.05 } \\
\text { significance) }\end{array}$ & $\begin{array}{c}p \text {-value } \\
(2 \text {-tail) }\end{array}$ & $\begin{array}{c}\text { t-critical } \\
(2 \text {-tail) }\end{array}$ \\
\hline Operating Profit Margin & 24.719 & 23.300 & 0.3805 & 0.7124 & $\mathbf{2 . 2 6 2 2}$ \\
Net Profit Margin & 13.685 & 7.061 & 1.3050 & 0.2243 & -do- \\
Return on Net worth & 14.183 & 7.047 & 1.3138 & 0.2214 & -do- \\
Return on Capital Employed & 15.224 & 9.371 & 1.1916 & 0.2639 & -do- \\
Debt Equity Ratio & 0.249 & 0.239 & 0.0983 & 0.9238 & -do- \\
\hline
\end{tabular}

( $\mathrm{t}$-values of 0.3805 and 1.3050). Likewise, average returns on net worth and capital employed show a decline during the post-merger period, but these are again not statistically significant ( $\mathrm{t}$-values of 1.3138 and 1.1916$)$. The debt equity ratio, which is typically very low for this sector, seems unchanged, post the mergers.

The above findings suggest that for the Information Technology Sector, mergers have caused a decline in profitability margins and returns on capital, indicating that for this industry, the motivation for mergers might be factors such as expanding product/service/technology portfolio, and may not translate into immediate operating benefits in the near term.

Based on the results in the study, the Null Hypothesis, that "Type of industry does not affect change in operating performance of acquiring companies following mergers" is being rejected.

\section{Discussion, Limitations and Suggestions for Further Analysis}

There have been different results obtained for different industry sectors, in terms of the impact on operating performance. While mergers seem to have improved profitability for the banking \& finance sector, they have caused significant decline in profitability in Organic \& Inorganic chemicals sector, and minor declines for other sectors. In terms of returns on Net Worth and capital employed, the results look more similar across industry sectors. While the returns have decreased significantly in case of Sugar \& Agri-products, and Organic \& Inorganic 
chemicals sectors, they have declined marginally in case of other industry sectors. The results indicate that the mergers in the banking and finance industry, which had aimed at efficiency and scope improvement, have been able to realize the objectives through improvement in profitability, while the same has not been significantly evident in other industry sectors in India during the period under study. The results agree with the findings of Pulak Mishra that M\&As did not have any significant impact on profitability of the firms in the Pharmaceutical Sector. They also agree with the findings of Azeem, Mantravadi and Neena for the Banking and Financial Services Industry, and those of Leepsa and Mishra who studied mergers in manufacturing sector in India. The findings differ from those of Bisma who studied M\&As in chemical and fertilizer sector of India. The variations in results across the different types of mergers as seen above, cause us to reject the null hypothesis, and state that there are differential levels of impact on operating performance of acquiring firms, for different industry sectors in India.

One limitation of the study was the small sample size for mergers in some of the industry sectors, as also for vertical mergers, in Indian context, which might not establish the statistical significance of some of the reported results. The study has also ignored the impact of possible differences in the accounting methods adopted by different companies in the sample, which could affect the results. The present study analysed the long-term impact analysis of mergers, using financial ratios, for the periods before and after mergers. This study contributes to existing research, by way of a comprehensive analysis, in terms of period of study, as well as the sample size, compared to other previous studies in Indian context, which have focused on short time periods, or on specific industries, with small sample sizes. Other performance studies have used cash flow as a measure, and this could be studied as extension of the current research study. Future research in this area could be an extension of the present study, by estimating and comparing with industry/sector averages, and the differences, if any could be probed further to derive further insights.

\section{Conflicts of Interest}

The author declares no conflicts of interest regarding the publication of this paper.

\section{References}

Agrawal, A., Jaffe, J. F., \& Mandelker, G. N. (1992). The Post-Merger Performance of Acquiring Firms: A Re-Examination of an Anomaly. Journal of Finance, 47, 1605-1621. https://doi.org/10.1111/j.1540-6261.1992.tb04674.x

Ahmed, M., \& Ahmed, Z. (2014). Mergers and Acquisitions: Effect on Financial Performance of Manufacturing Companies of Pakistan. Middle-East Journal of Scientific Research, 21, 706-716.

Ayorinde, A. O., \& Ramon, A. A. (2012). Effects of Merger and Acquisition on the Performance of Selected Commercial Banks in Nigeria. International Journal of Business 
and Social Research, 2, 148-157.

Beena, S. (2007). Mergers and Acquisitions in the Indian Pharmaceutical Industry: Nature, Structure and Performance. MPRA Paper, Munich: University Library of Munich.

Duggal, N. (2015). Post Merger Performance of Acquiring Firms: A Case Study on Indian Pharmaceutical Industry. International Journal of Research in Management \& Business Studies, 3, 24-28.

Ghosh, A. (2001). Does Operating Performance Really Improve Following Corporate Acquisitions? Journal of Corporate Finance, 7, 151-178.

https://doi.org/10.1016/S0929-1199(01)00018-9

Healy, P. M., Palepu, K. G., \& Ruback, R. S. (1992). Does Corporate Performance Improve after Mergers? Journal of Financial Economics, 31, 135-175. https://doi.org/10.1016/0304-405X(92)90002-F

Ikeda, K., \& Doi, N. (1983). The Performances of Merging Firms in Japanese Manufacturing Industry: 1964-75. The Journal of Industrial Economics, 31, 257-266.

https://doi.org/10.2307/2097886

Iordanis, E., Pazarskis, M., Christodoulou, P., \& Drogalas, G. (2012). Evaluating Post-Merger Performance and Risk at Conglomerate Mergers in Greece. Archives of Economic History, 14, 37-55.

Jiang, J. L. (2019). An Empirical Study on M\&A Performance: Evidence from Horizontal Mergers and Acquisitions in the United States. Open Journal of Business and Management, 7, 976-997. https://doi.org/10.4236/ojbm.2019.72066

Khan, A. A. (2012). Merger and Acquisitions (M\&As) in the Indian Banking Sector in Post Liberalization Regime. International Journal of Accounting and Financial Management Research, 2, 1-18.

Kruse, T. A., Park, H. Y., Park, K., \& Suzuki, K. (2003). Long-Term Performance Following Mergers of Japanese Companies: The Effect of Diversification and Affiliation. $\mathrm{Pa}$ cific Basin Finance Journal, 15, 154-172. https://doi.org/10.1016/j.pacfin.2006.07.001

Leepsa, N. M., \& Mishra, C. S. (2012). Post Merger Financial Performance: A Study with Reference to Select Manufacturing Companies in India. International Research Journal of Finance and Economics, 83, 6-17.

Lubatkin, M. (1983). Mergers and Performance of the Acquiring Firm. Academy of Management Review, 8, 218-225. https://doi.org/10.5465/amr.1983.4284724

Mantravadi, P., \& Reddy, A. V. (2008). Post-Merger Performance of Acquiring Firms from Different Industries in India. International Research Journal of Finance and Economics, 22, 193-204.

Martynova, M., Oosting, S., \& Renneboog, L. (1990). The Long-Term Operating Performance of European Acquisitions. In International Mergers and Acquisitions Activity since 1990: Quantitative Analysis and Recent Research (pp. 1-40). Boston, MA: Elsevier.

Mishra, P. (2019). How Have Mergers and Acquisitions Affected Financial Performance of Firms in Indian Manufacturing Sector? Eurasian Journal of Business and Economics, 12, 79-96. https://doi.org/10.17015/ejbe.2019.023.05

Mishra, P., \& Chandra, T. (2010). Mergers, Acquisitions and Firms' Performance: Experience of Indian Pharmaceutical Industry. Eurasian Journal of Business and Economics, 3, 111-126.

Musah, A., Abdulai, M., \& Baffour, H. (2020). The Effect of Mergers and Acquisitions on Bank Performance in Ghana. Asian Journal of Economics and Empirical Research, 7, 36-45. https://doi.org/10.20448/journal.501.2020.71.36.45 
Pawaskar, V. (2001). Effect of Mergers on Corporate Performance in India. Vikalpa, 26, 19-32. https://doi.org/10.1177/0256090920010103

Ramakrishnan, K. (2008). Long-Term Post-Merger Performance of Mergers in India. Vikalpa, 23, 47-63. https://doi.org/10.1177/0256090920080204

Rani, N., Yadav, S., \& Jain, P. K. (2013). Post-M\&A Operating Performance of Indian Acquiring Firms: A DuPont Analysis. International Journal of Economics and Finance, 5, 65-73. https://doi.org/10.5539/ijef.v5n8p65

Rani, N., Yadav, S., \& Jain, P. K. (2015). Financial Performance Analysis of Mergers and Acquisitions: Evidence from India. International Journal of Commerce and Management, 25, 402-423. https://doi.org/10.1108/IJCoMA-11-2012-0075

Shah, B. A. (2018). Measuring Post-Merger and Acquisition Performance in Chemical and Fertilizer Sector of India. Pacific Business Review International, 11, 2.

Sinha, N., Kaushik, K. P., \& Sachdeva, T. (2010). Measuring Post Merger and Acquisition Performance: An Investigation of Select Financial Sector Organizations in India. International Journal of Economics and Finance, 2, 190-200.

https://doi.org/10.5539/ijef.v2n4p190

Weston, J. F., \& Mansinghka, S. K. (1971). Tests of the Efficiency Performance of Conglomerate Firms. Journal of Finance, 26, 919-936. https://doi.org/10.1111/j.1540-6261.1971.tb00928.x

Zhang, W., Wang, K., Li, L., Chen, Y., \& Wang, X. (2018). The Impact of Firms' Mergers and Acquisitions on Their Performance in Emerging Economies. Technological Forecasting \& Social Change, 135, 208-216. https://doi.org/10.1016/j.techfore.2018.05.015 